\title{
PERANAN KETERANGAN SAKSI / AHLI DALAM PROSES PENYIDIKAN TINDAK PIDANA UNTUK MENUJU TERANGNYA KEADILAN DALAM PROSES HUKUM DI INDONESIA“
}

\author{
Gigik Tri MR ${ }^{1}$, Nurbaedah ${ }^{2}$ \\ 1. Kepolisian Daerah Jawa Timur \\ 2. Magister Hukum Program Pascasarjana Universitas Islam Kadiri \\ Email: mugiyotrigigik@gmail.com
}

\begin{abstract}
ABSTRAK
Pada masa HIR (Herziene Inlands Reglement), Keterangan ahli adalah keterangan yang diberikan oleh seorang yang memiliki keahlian khusus tentang hal yang diperlukan untuk membuat terang suatu perkara pidana guna kepentingan pemeriksaan.Peranan keterangan ahli dalam pemeriksaan perkara pidana dapat dilihat pengaturannya dari dua jenis ketentuan undang-undang yaitu menurut HIR (Herziene Inlands Reglement) dan menurut KUHAP (Kitab Undang Undang Hukum Acara Pidana). Dalam HIR, keterangan ahli tidak termasuk alat bukti dalam pembuktian perkara pidana.

Menurut Pasal 80 HIR menyatakan bahwa menjadi saksi dalam suatu perkara pidana itu merupakan suatu kewajiban dan apabila dilalaikan ada sanksinya, akan tetapi tidak semua orang wajib menjadi saksi. Tiap-tiap orang yang tidak dikecualikan dalam undang-undang.

Terkait dengan bantuan keterangan ahli yang diperlukan dalam proses pemeriksaan suatu perkara pidana, maka bantuan ini pada tahap penyidikan juga mempunyai peran yang cukup penting untuk membantu penyidik mencari dan mengumpulkan bukti-bukti dalam usahanya menemukan kebenaran materiil suatu perkara pidana. Dasar hukum bagi pemeriksaan ahli dalam tingkat penyidikan jelas terlihat dalam Pasal 120 KUHAP. Dimana penyidik dapat meminta pendapat seorang ahli dalam hubungannya dengan pemeriksaan perkara ditingkat penyidikan, Dalam kasuskasus tertentu, bahkan penyidik sangat bergantung terhadap keterangan ahli untuk mengungkap lebih jauh suatu peristiwa pidana yang sedang ditanganinya. Kasus-kasus tindah pidana seperti pembunuhan, penganiayaan dan perkosaan merupakan contoh kasus dimana penyidik membutuhkan bantuan tenaga ahli seperti dokter ahli forensik atau dokter ahli lainnya, untuk memberikan keterangan medis tentang kondisi korban yang selanjutnya cukup berpengaruh bagi tindakan penyidik dalam mengungkap lebih lanjut kasus tersebut.
\end{abstract}

Kata Kunci :menurut HIR (Herriene Inlands Reglement) dan menurut KUHAP (Kitab Undang Undang Hukum Acara Pidana). Dalam HIR, keterangan ahli tidak termasuk alat bukti dalam pembuktian perkara pidana..

\section{ABSTRAK}

At the time of the HIR (Heriene Inlands Reglement), the Expert Description is the information given by a person who has special expertise on what is required to make the light of a criminal case in the interest of the examination. The role of expert information in the investigation of criminal cases can be seen from two types of legal provisions, according to the HIR (Herziene Inlands Reglement) and according to the Criminal Procedure Code (Criminal Procedure Code). In HIR, expert information does not include evidence in the evidence of a criminal case.

According to Article 80 HIR states that being a witness in a criminal case is an obligation and if dilalaikan there are sanctions, but not everyone is required to be a witness. Each person is not excluded in the law.

In relation to the assistance of expert information required in the process of examining a criminal case, this assistance at the investigation stage also bas an important role to assist investigators to seek and collect evidence in an attempt to discover the material truth of a criminal case. The legal basis for expert examination in the investigation level is clearly seen in Article 120 of the Criminal Procedure Code. Where investigators can seek an expert's opinion in relation to examination of the case at the investigation level, In some cases, even the investigator relies heavily on the expert's explanation to further disclose a criminal incident in his hand. Criminal cases such as murder, ill-treatment and rape are examples of cases where investigators need the assistance of experts such as forensic physicians or other 
physicians, to provide medical information about the condition of the victim, which further affects the action of the investigator in further disclosing the case

Keywords: according to HIR (Herziene Inlands Reglement) and according to Criminal Procedure Code (Criminal Procedure Code). In the HIR, expert information does not include evidence in the evidence of a criminal case.

\section{A. PENDAHULUAN}

Ada kecenderungan yang menarik untuk dikaji didalam praktik penegakan hukum di Indonesia. Peran keterangan ahli menjadi kian menonjol dan ada cukup banyak perkara yang menggunakan keterangan ahli sebagai dasar Justifikasi didalam memutus perkara pidana. Hal ini disebabkan karena pada hakekatnya, pemeriksaan suatu perkara pidana didalam suatu proses peradilan bertujuan untuk mencari kebenaran mareriil (materile waarheid) terhadap perkara tersebut. Hal ini dapat dilihat dari adanya berbagai usaha yang dilakukan oleh aparat penegak hukum dalam memperoleh bukti-bukti yang dibutuhkan untuk mengungkap suatu perkara baik pada tahap pemeriksaan pendahuluan seperti penyidikan dan penuntutan maupun pada tahap persidangan perkara tersebut. ${ }^{1}$

Usaha-usaha yang dilakukan oleh para penegak hukum untuk mencari kebenaran materiil suatu perkara pidana dimaksudkan untuk menghindari adanya kekeliruan dalam menjatuhkan pidana terhadap diri seseorang, hal ini sebagaimana ditentukan dalam Undang-Undang No. 14 Tahun 1970 tentang Ketentuan Pokok Kekuasaan Kehakiman Pasal 6 ayat (2) yang menyatakan : "Tiada seorang juapun dapat dijatuhi pidana, kecuali apabila pengadilan karena alat pembuktian yang sah menurut Undang-Undang mendapat keyakinan bahwa seseorang yang dianggap dapat bertanggungjawab, telah bersalah atas perbuatan yang dituduhkan atas dirinya". Dengan adanya ketentuan perundang-undangan diatas, maka dalam proses penyelesaian perkara pidana penegak hukum wajib mengusahakan pengumpulan bukti maupun fakta mengenai perkara pidana yang ditangani dengan selengkap mungkin. Adapaun mengenai alat-alat bukti yang sah sebagaimana dimaksud diatas dan yang telah ditentukan menurut ketentuan Perundang-undangan adalah sebagaimana diatur dalam Undang-Undang No.8 Tahun 1981 tentang Kitab Undang-undang Hukum Acara Pidana (KUHAP) pada pasal 184 ayat (1). Didalam usaha memperoleh bukti-bukti yang diperlukan guna kepentingan pemeriksaan suatu perkara pidana, sering kali para penegak hukum dihadapkan pada suatu masalah atau hal-hal tertentu yang tidak dapat diselesaikan sendiridikeranakan masalah tersebut berada diluar kemampuan atau kehaliannya. Dalam hal demikian maka bantuan seorang ahli sangat penting diperlukan dalam rangka mencari kebenaran materiil selangkap-lengkapnya bagi para penegak hukum tersebut. ${ }^{2}$

Mengenai perlunya bantuan seorang ahli dalam memberikan keterangan yang terkait dengan kemampuan dan keahliannya untuk membantu pengungkapan dan pemeriksaan suatu perkara pidana, Prof. A. Karim Nasution menyatakan : "Meskipun pengetahuan, pendidikan dan pengalaman dari seseorang mungkin jauh lebih luas daripada orang lain, namun pengetahuan dan pengalaman setiap manusia tetap terbatas adanya. Maka oleh sebab itulah selalu ada kemungkinan bahwa soal-soal yang tidak dapat dipahami secukupnya oleh seorang penyidik dalam pemeriksaan pendahuluan, ataupun seorang hakim di muka persidangan sehingga ia perlu diberi pertolongan oleh orang-orang yang memiliki sesuatu pengetahuan tertentu. Agar tugas-tugas menurut hukum acara pidana dilaksanakan dengan sebai-baiknya, maka oleh Undang-Undang diberi kemungkinan agar Penyidik dan para Hakim dalam keadaan yang khusus dapat memperoleh bantuan dari orangorang yang berpengetahuan dan berpengalaman khusus tersebut. ${ }^{3}$

Bantuan seorang ahli yang diperlukan dalam suatu proses pemeriksaan perkara pidana, baik pada tahap pemeriksaan pendahuluan dan pada tahap pemeriksaan lanjutan di sidang pengadilan, mempunyai peran dalam membantu aparat yang berwenang untuk membuat terang suatu perkara pidana, mengumpulkan bukti-bukti yang memerlukan keahlian khusus, memberikan petunjuk yang

${ }^{1}$ Peranan Visum Et Repertum Pada tahap Penyidikan Dalam Mengungkap Tindak Pidana Pemerkosaan, http://www.lawskripsi.com/article.php, diakses pada tanggal 23 Maret 2009

${ }^{2} \mathrm{Ibid}$

3 Ibid 
lebih kuat mengenai pelaku tindak pidana, serta pada akhirnya dapat membantu hakim dalam menjatuhkan putusan dengan tepat terhadap perkara yang diperiksanya. Pada tahap pemeriksaan pendahuluan dimana dilakukan proses penyidikan atas suatu peristiwa yang diduga sebagai suatu tindak pidana, tahapan ini mempunyai peran yang cukup penting bahkan menentukan untuk tahap pemeriksaan selanjutnya dari kesleuruhan proses peradilan pidana. Tindakan penyidikan yang dilakukan oleh pihak Kepolisian atau pihak lain yang diberi wewenang oleh undang-undang untuk melakukan tindakan penyidikan, bertujuan untuk mencari serta mengumpulkan bukti yang dengan bukti tersebut dapat membuat teranng tindak pidana yang terjadi dan guna menemukan tersangkanya. Berdasarkan hasil yang didapat dari tindakan penyidikan suatu kasus pidana, hal ini selanjutnya akan diproses pada tahap penuntutan dan persidangan di pengadilan. ${ }^{4}$

Menempatkan keterangan ahli sebagai alat bukti yang sah, merupakan hal yang dapat dicatat sebagai salah satu kemajuan dalam pembaruan hukum. Mungkin pembuat undang-undang menyadari bahwa sudah tidak dapat dipungkiri lagi pada saat perkembangan ilmu dan teknologi, keterangan ahli memegang peranan dalam penyelesaian kasus pidana, sebagai contoh ketika aparat penegak hukum, khususnya Kejaksaan, mengusut kasus korupsi, maka peranan ahli menjadi dibutuhkan, dalam hal ini dalam hal keuangan negara, hukum pidana, dan hukum tata negara/ hukum administrasi negara. Sebagai suatu tindak pidana dalam ranah publik, maka peranan ahli dibutuhkan untuk menjernihkan pemahaman terutama kepada hakim, bagaimana konstruksi hukum yang semestinya dibangun dari hasil penyidikan, dakwaan dan tuntutan yang disampaikan di pengadilan. ${ }^{5}$

Didalam konteks itu ada kebutuhan untuk mengatur ahli agar sesuai dengan kapasitas keahliannya dan si ahli tidak sedang menjadi Tim Advokasi atau Lawyer dari satu pihak sehingga dapat mempengaruhi kapasitas obyektifitas keahliannya. Dalam HIR (Herziene Inlands Reglement). Keterangan ahli tidak termasuk alat bukti dalam pemeriksaan perkara pidana. HIR tidak memandang keterangan ahli sebagai alat bukti yang sah, tetapi hanya dipakai guna memberi penerangan pada hakim, dan hakim sama sekali tidak wajib turut pada pendapat orang-orang ahli itu, apabila keyakinan hakim bertentangan dengan pendapat ahli-ahli itu. Selanjutnya kalau hakim setuju dengan pendapat seorang ahli itu, maka pendapat itu diambil oleh hakim dan dianggap sebagai pendapatnya sendiri. Dengan berlakunya KUHAP (Kitab Undang-Undang Hukum Acara Pidana) Pasal 184 ayat (1) menetapkan keterangan ahli sebagai alat bukti yang sah. Bahkan tempatnya diletakan pada urutan kedua sesudah alat bukti keterangan saksi. Melihat letak urutannya, pembuat Undang-Undang menilainya sebagai salah satu alat bukti yang penting yang artinya dalam pemeriksaan perkara pidana. ${ }^{6}$

Berdasarkan penjelasan pasal 186 KUHAP (Kitab Undang-Undang Hukum Acara Pidana) menyatakan bahwa keterangan ahli ini dapat juga sudah diberikan pada waktu pemeriksaan oleh penyidik atau penuntut umum yang dituangkan dalam suatu bentuk laporan dan dibuat dengan mengingat sumpah diwaktu ia menerima jabatan atau pekerjaan. Jika hal itu tidak diberikan pada waktu pemeriksaan oleh penyidik atau penuntut umum, makapada pemeriksaan disidang, diminta untuk memberikan keterangan dan dicatat dalam berita acara pemeriksaan. Keterangan tersebut diberikan setelah ia mengucapkan sumpah atau janji dihadapan hakim, misalnya dalam suatu kasus seorang korban yang tidak terdapat luka pada badannya tetapi sebelum ia meninggal dunia, ada halhal padanya yang menimbulkan persangkaan bahwa ia telah diracun, maka seorang ahli kimia harus diminta pertolongan untuk memeriksa isi perut si korban dan mengajukan pendapat tentang sebab dari kematian si korban. Dari contoh ini orang ahli mengemukakan pendapat tentang sebab dari kematian korban. Kalau pendapat seorang ahli tentang sebab itu disetujui oleh hakim, maka hakim menganggap adanya sebab itu, dan sebetulnya hakim menganggap terbukti pembunuhan itu antara

${ }^{4} \mathrm{Ibid}$

${ }^{5}$ Isharyanto, Keterangan Abli Sebagai Pengembanan Hukum Untuk Pencerahan Hukum, http://www.hukum.com/makalah-seminar, diakses pada tanggal 23 Maret 2009

${ }^{6}$ M. Yahya Harahap, Pembahasan Permasalahan dan Penerapan KUHAP, Pemeriksaan Sidang Pengadilan, Banding, Kasasi dan Peninjauan Kembali, Sinar Grafika, Jakarta, 2006, hal. 295 
lain dengan mempergunakan pendapat ahli tentang sebab itu. Dilihat dari sudut ini, maka jelaslah bahwa keterangan ahli dapat dinamakan juga alat bukti. ${ }^{7}$

Dengan demikian, jelaslah bahwa keterangan memegang peranan dalam penyelesaian kasus pidana. Perkembangan ilmu dan teknologi sedikit banyak membawa dampak terhadap kualitas metode kejahatan, memaksa agar mengimbanginya dengan kualitas dan metode pembuktian yang memerlukan pengetahuan dan keahlian. ${ }^{8}$

\section{B. METODE}

Metode diartikan sebagai suatu jalan atau cara untuk mencapai sesuatu. Sebagaimana tentang cara penelitian harus dilakukan, maka metode penelitian yang digunakan penulis mencakup anatar lain :

Jenis penelitian yang digunakan adalah penelitian yang menggabungkan anatara penelitian hukum normatif (penelitian hukum doktrinal) dan penelitian hukum sosiologi (penelitian hukum empiris). Penelitian hukum normatif disebut juga penelitian kepustakaan atau studi dokumen. Penelitian hukum normatif disebut hukum doktriner, karena penelitian dilakukan atau ditujukan hanya pada peraturan-peraturan yang tertulis atau bahan hukum yang lain. Penelitian hukum ini juga disebut dengan penelitian kepustakaan ataupun studi dokumen disebabkan penelitian ini lebih banyak dilakukan terhadap data yang bersifat sekunder yang ada di perpustakaan. Penelitian kepustakaan demikian dapat pula dikatakan sebagai lawan dari penelitian empiris (penelitian lapangan).

Penelitian hukum sosiologi mempunyai istilah lain yaitu penelitian hukum empiris dan dapat juga disebut dengan penelitian lapangan. Penelitian hukum sosiologi ini beritik dari data primer. Data primer (data dasar) adalah data yang didapat lengsung dari masyarakat sebagai sumber pertama dengan melalui penelitian lapangan. Perolehan data primer dari penelitian lapangan dapat dilakukan baik melalui pengamatan, wawancara ataupun penyebaran kuisioner.

Materi dalam penelitian ini diambil dari data primer dan data sekunder. Jenis data yang meliputi data primer yaitu Field Research (penelitian lapangan), yaitu dengan meneliti langsung ke lapangan mengenai peranan keterangan ahli dalam pemeriksaan perkara pidana ditingkat penyidikan dalam hal ini dalam wilayah kerja Polres Kota Kediri.

Penelitian atau studi lapangan dilakukan melalui wawancara dengan anggota Kepolisian Resor Kota Kediri selaku Penyidik di Reserse Kriminal Polres Kota Kediri dan seorang pakar hukum selaku saksi ahli, sehingga memperoleh salinan data-data yang lebih lengkap dan menunjang pembahasan permasalahan yang disusun penulis.

Data sekunder diperoleh dengan cara libraryresearch (penelitian kepustakaan), yaitu dengan melakukan penelitian terhadap berbagai sumber bacaan, buku-buku, berbagai literatur, dan juga berbagai peraturan perundang - undangan yang berkaitan dengan peranan keterangan ahli dalam pemeriksan perkara pidana ditingkat penyidikan.

Data yaang telah diperoleh melalui studi pustaka diklasifikasi dan diurutkan kedalam pola, kategori dan satuan uraian dasar. ${ }^{9}$ Keseluruhan data akan diuraikan secara deskriptif yang kemudian akan dianalisa secara kualitatif. Analisa data secara kualitatif dimulai dengan menelaah data yang tersedia dari berbagai sumber yang telah didapatkan, kemudian setelah dipelajari dan ditelaah langkah selanjutnya adalah menyusunnya kedalam satuan-satuan dan kemudian dikategorisasikan dan yang terakhir adalah melakukan penafsiran data menjadi teori substansi dengan menggunakan beberapa metode tertentu. ${ }^{10}$

Berdasarkan hal tersebut dapat dikatakan bahwa apa yang dimaksud dengan metode kualitatif adalah suatu tata cara penelitian yang menghasilkan data deskriptif-analisis, yaitu apa yang dinyatakan oleh responden secara tertulis atau lisan, dan juga perilakunya yang nyata, dipelajari dan

\footnotetext{
${ }^{7}$ Ibid, hal 296

${ }^{8}$ Ibid.

${ }^{9}$ Ibid.,hal. 103

${ }^{10}$ Ibid.,hal. 190
} 
diteliti sebagai sesuatu yang utuh. Metode kualitatif tidak hanya bertujuan mengungkap kebenaran tetapi juga memahami kebenaran tersebut dan latar belakang terjadinya suatu peristiwa. ${ }^{11}$

\section{PEMBAHASAN}

Pada masa HIR (Herziene Inlands Reglement), keterangan ahli tidak termasuk alat bukti dalam pembuktian perkara pidana. Adapaun yang dimaksud dengan alat-alat bukti adalah alat-alat yang ada hubungannya dengan suatu kejahatan dimana alat-alat tersebut dapat dipergunakan sebagai bahan pembuktian guna menimbulkan keyakinan hakim atas kebenaran adanya tindak pidana yang telah dilakukan oleh tertuduh. HIR tidak memandang keterangan ahli sebagai alat bukti yang sah, tetapi menganggapnya sebagai keterangan keahlian yang dapat dijadikan hakim menjadi pendapatnya sendiri, jika hakim menilai keterangan ahli tersebut dapat diterima.Pada masa HIR (Herziene Inlands Reglement), keterangan ahli tidak termasuk alat bukti dalam pembuktian perkara pidana. Adapaun yang dimaksud dengan alat-alat bukti adalah alat-alat yang ada hubungannya dengan suatu kejahatan dimana alat-alat tersebut dapat dipergunakan sebagai bahan pembuktian guna menimbulkan keyakinan hakim atas kebenaran adanya tindak pidana yang telah dilakukan oleh tertuduh. HIR tidak memandang keterangan ahli sebagai alat bukti yang sah, tetapi menganggapnya sebagai keterangan keahlian yang dapat dijadikan hakim menjadi pendapatnya sendiri, jika hakim menilai keterangan ahli tersebut dapat diterima.

Pembuktian merupakan titik sentral pemeriksaan perkara dalam sidang pengadilan. Pembuktian adalah ketentuan-ketentuan yang berisi garisan dan pedoman tentang cara-cara yang dibenarkan undang-undang membuktikan kesalahan yang didakwakan kepada terdakwa. Disamping itu juga merupakan ketentuan yang mengatur alat-alat bukti yang dibenarkan undang-undang dan yang boleh dipergunakan hakim membuktikan kesalahan yang didakwakan. ${ }^{12}$

Dari utaian diatas dapat dilihat bahwa pengertian pembuktian adalah ketentuan yang dibatasi sidang pengadilan dalam usahanya mencari dan menemukan kebenaran. Para instansi terkait dalam pemeriksaan perkara pidana terikat ketentuan tata cara dan penilaian alat bukti yang ditentutkan undang-undang. Mereka tidak boleh bertindak dengan caranya sendiri dalam penilaian pembuktian. Dalam mempergunakan alat bukti, tidak boleh bertentangan dengan undang-undang. Demikian pula dalam cara mempergunakan dan menilai kekuatan pembuktian yang melekat pada setiap alat bukti, harus dilaksanakan dalam batas-batas yang dibenarkan undang-undang.

Semenjak berlakunya Kitab Undang-Undang Hukum Acara Pidana disingkat KUHAP (undang-undang Nomor 8 Tahun 1981. LN Th.1981 No. 76, TLN. No.3209) yang mencabut HIR (Stb.Th.1941 No.44) jo Undang-Undang Nomor.1/Drt Th.1951 (LN.Th.1951 No.9) jo Ketentuan Hukum Acara Pidana dan Peraturan Perundang-Undangan lain, maka ketentuan perihal macammacam alat bukti yang sah tentang pembuktian dalam proses pemeriksaan disidang pengadilan menjadi lebih lengkap, yaitu dengan dimasukkannya secara tegas alat bukti "keterangan ahli" didalam Pasal 184. Dalam HIR, keterangan ahli bukan merupakan alat bukti yang sah, keterangan ahli hanya merupakan pendapat atau keterangan yang diberikan kepada hakim, oleh karena itu tidak mengikat hakim dan dapat mengeyampingkan keterangan ahli tersebut.

Terkait dengan bantuan keterangan ahli yang diperlukan dalam proses pemeriksaan suatu perkara pidana, maka bantuan ini pada tahap penyidikan juga mempunyai peran yang cukup penting untuk membantu penyidik mencari dan mengumpulkan bukti-bukti dalam usahanya menemukan kebenaran materiil suatu perkara pidana. Dalam kasus-kasus tertentu, bahkan penyidik sangat bergantung terhadap keterangan ahli untuk mengungkap lebih jauh suatu peristiwa pidana yang sedang ditanganinya. Kasus-kasus tindah pidana seperti pembunuhan, penganiayaan dan perkosaan merupakan contoh kasus dimana penyidik membutuhkan bantuan tenaga ahli seperti dokter ahli forensik atau dokter ahli lainnya, untuk memberikan keterangan medis tentang kondisi korban yang

\footnotetext{
${ }^{11}$ Soejono Soekanto, Pengantar Penelitian Hukum, UI-Press, Jakarta, 1986, hal. 250

${ }^{12}$ M. Yahya Harahap, Pembahasan Permasalahan dan Penerapan KUHAP, Pemeriksaan Sidang Pengadilan, Banding, Kasasi dan Peninjauan Kembali, Penerbit Sinar Grafika, Jakarta, 2006,hal.273.
} 
selanjutnya cukup berpengaruh bagi tindakan penyidik dalam mengungkap lebih lanjut kasus tersebut. ${ }^{13}$

Dalam pemeriksaan perkara pidana ditingkat penyidikan, terkadang penyidik mengalami kesulitan menentukan pasal mana yang berlaku terhadap perkara pidana yang sedang diperiksa. Oleh karena itu, penyidik dapat memanggil dan meminta keterangan ahli agar peristiwa pidana yang sedang diperiksa dapat terungkap lebih terang. Keterangan ahli ini diminta oleh penyidik untuk mengambil suatu pertimbangan tentang fakta hukum yang sedang disidik dengan keterangan yang diberikan oleh ahli tersebut sehingga dapat membantu penyidik untuk lebih memastikan pasal yang dikenakan terhadap perkara pidana yang sedang diperiksa. ${ }^{14}$ Keterangan ahli juga berfungsi untuk memberi masukan bagi penyidik dalam menempatkan atau memperjelas suatu perkara pidana yang sedang diperiksa ataupun untuk memposisikan fakta perkara itu apakah sudah terpenuhi atau tidak terhadap pasal-pasal yang dikenakan bagi tersangka. ${ }^{15}$

Pemeriksaan keterangan ahli hanya apabila penyidik menganggap perlu, terutama terhadap orang-orang yang memiliki keahlian khusus, dengan maksud agar peristiwa tindak pidana yang sedang dilakukan penyidikan semakin terang. Jadi, peranan keterangan ahli dalam proses pemeriksaan perkara pidana ditingkat penyidikan adalah membuat terangnya suatu tindak pidana yang terjadi.

Dalam melaksanakan tugas dan fungsinya ditingkat penyidikan, tidak jarang penyidik menghadapai hambatan ataupun kendala dalam hal memperoleh keterangan ahli guna membantu penyidik mengungkap suatu perkara pidana. Hambatan yang sering dihadapi penyidik adalah hambatan dari segi kemampuan aparat kepolisian, yaitu dalam hal memahami keterangan yang diberikan oleh seorang ahli. Hal ini disebabkan karena terkadang tidak selamanya ahli dalam satu bidang yang sama memberikan keterangan yang sama pula terhadap suatu perkara pidana yang sama. Dengan demikian, penyidik tidak dapat hanya berpatokan pada satu keterangan ahli saja, karena dapat saja penyidik meminta lebih dari satu ahli untuk memberikan keterangan terhadap satu perkara pidana.

Dalam hal menghadapi hambatan-hambatan yang dijumpai penyidik dalam memperoleh kketerangan ahli tersebut diatas, tentunya ada upaya-upaya yang dilakukan oleh penyidik untuk mengatasi hambatan tersebut. Upaya-upaya yang dilakukan penyidik dalam mengatasi hambatan dari segi kemampuan aparat kepolisian yaitu dengan lebih mengamati dan mencermati setiap keterangan yang diberikan oleh ahli tersebut. Sehingga keterangan yang diberikan oleh ahli itu benar-benar dapat membantu penyidik dalam memperjelas suatu perkara pidana yang sedang diperiksa. Dan tidak segan-segan untuk meminta keterangan ahli tersebut kembali apabila penyidik belum memahami keterangan ahli tersebut. ${ }^{16}$

Sedangkan upaya yang dilakukan penyidik dalam mengatasi hambatan dari segi budaya hukum masyarakat yaitu dengan memberikan keterangan ataupun penjelasan kepada pihak-pihak yang berperkara baik terhadap korban maupun pelaku tindak pidana mengenai perlu adanya keterangan ahli dalam kasus yang sedang diperiksa oleh penyidik.

\section{KESIMPULAN}

Setelah melakukan pembahasan terhadap permasalahan yang menjadi rumusan masalah dalam penulisan tesis ini, maka penulis akhirnya sampai pada suatu kesimpulan dari pembahasan. Kesimpulan tersebut akan diuraikan lebih lanjut dalam poin-poin sebagai berikut :

Keterangan ahli adalah keterangan yang diberikan oleh seorang yang memiliki keahlian khusus tentang hal yang diperlukan untuk membuat terang suatu perkara pidana guna kepentingan pemeriksaan.Peranan keterangan ahli dalam pemeriksaan perkara pidana dapat dilihat

\footnotetext{
${ }^{13}$ Wawancara dengan AIPDA Erman Tanjung, Penyidik Sat I Pidum Dit Reskrim Polda Jatim, pada tanggal 28 April 2014.

${ }^{14}$ Wawancara dengan BRIPKA Luth Jhonson,SH, Penyidik pada Reserse Kriminal, pada tanggal 10 Maret 2014 di Reskrim Polres Mojokerto.

${ }^{15}$ Wawancara dengan Dr. Mahmud Mulyadi, SH. M. Hum, seorang ahli hukum pidana.

${ }^{16}$ Ibid.
} 
pengaturannya dari dua jenis ketentuan undang-undang yaitu menurut HIR (Herieiene Inlands Reglement) dan menurut KUHAP (Kitab Undang Undang Hukum Acara Pidana). Dalam HIR, keterangan ahli tidak termasuk alat bukti dalam pembuktian perkara pidana.

Dasar hukum bagi pemeriksaan ahli dalam tingkat penyidikan jelas terlihat dalam Pasal 120 KUHAP. Dimana penyidik dapat meminta pendapat seorang ahli dalam hubungannya dengan pemeriksaan perkara ditingkat penyidikan. Namun dalam memperoleh keterangan ahli tersebut terkadang penyidik menemui berbagai hambatan seperti hambatan yang datang dari kemampuan si penyidik. Dalam hal ini, penyidik mengalami kesulitan untuk memahami keterangan yang diberikan oleh ahli tersebut.

\section{E. DAFTAR PUSTAKA}

Chazawi, Adami, 2002. Pelajaran Hukum Pidana I. PT. Raja Grafindo Persada, Jakarta.

Hamid, H. Hamrat, dan Harun M. Husein, 1992. Pembahasan Permasalaban KUHAP Bidang Pendidikan. Sinar Grafika, Jakarta

Hamzah, Andi, 1993. Hukum Acara Pidana. Arikha Media Cipta, Jakarta.

Harahap, M. Yahya, 2006. Pembahasan Permasalahan dan Penerapan KUHAP bidang Penyidikan dan Penuntutan. Penerbit Sinar Grafika, Jakarta.

M. Yahya, 2006. Pembahasan Permasalahan dan Penerapan KUHAP bidang Pemeriksaan Sidang Pengadilan, Banding, Kasasi dan Peninjauan Kembali, Penerbit Sinar Grafika, Jakarta.

Husein, Harun M., 1991. Penyidikan dan Penuntutan dalam Proses Pidana, PT. Rineka Cipta, Jakarta.

Kartanegara, Satochid, Hukum Pidana (Kumpulan Kuliah) Bagian I. Balai Lektur Mahasiswa.

Nico, Ngani, I Nyoman Budi Jaya dan Hasan Madani, 1984. Mengenal Hukum Acara Pidana Bagian Umum dan Penyidikan, Liberty, Yogyakarta.

Marpaung, Leden, 1991. Unsur - unsur Perbuatan Yang Dapat Dibukum. Sinar Grafika, Jakarta.

Prakoso, Djoko, 1987. Penyidik, Penuntut Umum, Hakim Dalam Proses Hukum Acara Pidana. PT. Bina Aksara, Jakarta.

Pradjodikoro, Wirjono, 1971. Hukum Acara Pidana di Indonesia. Subur, Bandung. , Wirjono, 1980. Tindak - tindak Pidana Tertentu di Indonesia, PT. Eresco, Bandung.

Ranoemihardjo, Atang R., 1980. Hukum Acara Pidana. Tarsito, Bandung.

Sabuan, Ansori, Syarifuddin Pettanasse dan Ruben Achmad, 1990. Hukum Acara Pidana. Angkasa, Bandung.

Sapardjaja, Komariah E, 2005. Ajaran Melawan Hukum Materil dalam Hukum Pidana Indonesia. Prenada Media, Jakarta.

Sari, Ratna, 1995. Penyidikan dan Penuntutan Dalam Hukum Acara Pidana. Kelompok Studi Hukum FH-USU, Medan.

Sasangka, Hari dan Lily Rosita, 2003. Hukum Pembuktian Dalam Perkara Pidana. CV. Mandar Maju, Bandung.

Soekanto, Soerjono, 1986. Pengantar Penelitian Hukum. UI - Press, Jakarta.

Soeparmono, R., 2002. Keterangan Abli dan Visum Et Repertum dalam Aspek. Hukum Acara Pidana. CV. Mandar Maju, Bandung.

Soesilo, R., 1979. RIB/HIR dengan Penjelasan. Politeia, Bogor.

Waluyadi, 1999. Pengetahuan Dasar Hukum Acara Pidana. CV. Mandar Maju, Bandung.

Yudowidagdo, Hendrastanto, 1987. Kapita Selekta Hukum Acara Pidana di Indonesia. Bina Aksara, Jakarta.

Undang - undang No. 8 Tahun 1981 Tentang Kitab Undang - Undang Hukum Acara Pidana. RIB/ HIR beserta Penjelasan. 